\title{
Adequacy of Flood Relief Shelters: A Case Study in Perak, Malaysia
}

\author{
Nur Zawani Zahari ${ }^{*}$, and Ahmad Mustafa Hashim ${ }^{1}$ \\ ${ }^{1}$ Department of Civil and Environmental Engineering, Universiti Teknologi PETRONAS, 32610 \\ Bandar Sri Iskandar, Perak, Malaysia
}

\begin{abstract}
The recent flood event occurred in 2014 had caused disastrous effects in Peninsular Malaysia in states of Kelantan, Pahang, Terengganu, Perak, Johor and Perlis. Perak state was reported with 12,115 victims from 2,896 families registered at 77 relief shelters. There are several issues encountered by the victims and related agencies which caused inconveniences and interruptions during the flooding period. Besides, the usage of public buildings as relief shelters contributes to deterioration of the infrastructures whereby their suitability, convenient, capacity and safety might not be optimum for longer period of time. This paper focuses on the assessment of relief shelters established in Perak Tengah district, Perak. Standards and guidelines for relief shelters were reviewed according to the most relevant agreed principles for humanitarian response. Data and information in this study were obtained from survey activities, interview sessions and observations. In Perak Tengah, more than $50 \%$ of the previous relief shelters were public buildings with low capacity areas. Strategic location of shelters with proper design standards should be established to ensure safe and healthy environment for the victims. Findings from this paper provide important outcomes to serve as better preparation in handling future disaster.
\end{abstract}

\section{Introduction}

Flood is the most devastating and costly natural hazards in the world that leads to significant economic and social damages [1-3]. Malaysia had experienced several major floods in the last few decades due to monsoon rainfall throughout the year [4]. Average rainfall of approximately $2,500 \mathrm{~mm}$ a year for all states in Malaysia making it one of the countries with the heaviest rainfall in the world [5]. In 1926, a worst memory of flood event caused severe damages at several states in Malaysia. Another disastrous floods back in 1967 and 1971 surged across the states in Malaysia that left huge impacts in the flood history $[1,6]$. Heavy monsoon rainfall in the year of 2006-2008 had also led to flooding in some of the affected states in Peninsular Malaysia [1,6]. The recent major flood event in Peninsular Malaysia in December 2014 to January 2015 had caused tremendous damage to several states including Kelantan, Pahang, Terengganu, Perak, Johor and Perlis [4, 7].

\footnotetext{
* Corresponding author : wanie.zahari@gmail.com
} 
Causative factors of floods are interrelated between various weather factors such as heavy rain, storm surges, inadequate drainage systems and structural failures of dams [8]. Nevertheless, people living within the flood plain areas or in close proximity to geographic regions such as coastal areas and river basins are vulnerable to flooding $[8,9]$. Relief shelters play a vital role as part of disaster response and recovery in providing optimum security, personal safety, protection from climate and improve resistance to ill health and diseases for victims who lost their accommodations as a result from the disaster itself [1011]. When a disaster happened, most of the evacuees particularly the elderly and low income communities rely on the relief shelters for their temporary house or shelters [12]. However, some of the evacuees were either stayed in hotels, relatives' houses, or even reluctant to leave their own houses in the times of flooding. Living in sheltered places with unfamiliar people may lead to invasion of personal space and privacy of the evacuees [7].

Relief shelters are not only function as immediate and short-term shelter for the victims but also help them to recover from trauma of the disaster as well as provide a base to start rehabilitation process [10]. Victims from disasters are not only require financial support due to losses and property damages, but some of them may need physical and emotional support after experiencing unexpected situations [13]. Since relief shelters may be used for several weeks or even months after a disaster period, numerous factors should be taken into account in planning and designing the shelters such as physical location and needs of likely users [10]. As a long-term flood disaster management strategy, a series of dedicated and well-designed relief shelters should be seriously considered. This paper presents the general standards of relief shelters and assessment of relief shelters established in Perak Tengah district, Perak.

\section{Relief shelters standards and guidelines}

The handbook of Humanitarian Charter and Minimum Standards in Disaster Response as compiled by The Sphere Project and Handbook for Emergencies by The United Nations High Commissioner for Refugee (UNHCR) had been classified as the most relevant agreed principles for response [14].

\subsection{The Sphere Project - Humanitarian Charter and Minimum Standards in Disaster Response}

\subsubsection{Description}

The Sphere Project was initiated by a group of humanitarian non-governmental organizations (NGOs) and the International Red Cross and Red Crescent Movement to develop a set of universal minimum standards for humanitarian response during the disaster. The handbook is the product of collective experiences of many people and agencies based on two core beliefs, first is that those affected by disaster or conflict have a right to live with dignity and receive assistance, second is that all possible steps should be taken to alleviate human suffering arising out of disaster or conflict [11]. A set of minimum standards are identified which describe conditions that must be achieved for disasteraffected populations to survive and recover in stable conditions and dignity [11].

\subsubsection{Minimum standard for relief shelter}

Table 1 shows the minimum standards in humanitarian response according to the standards specified in The Sphere Project handbook [11]. 
Table 1. Minimum standards in humanitarian response [11].

\begin{tabular}{|c|l|}
\hline Minimum Standard & \multicolumn{1}{c|}{ Description } \\
\hline Type of Shelter & $\begin{array}{l}\text { Tents, plastic sheeting, prefabricated buildings, temporary or } \\
\text { transitional shelters, permanent public buildings. }\end{array}$ \\
\hline Living Area & Covered area of 3.5 $\mathrm{m}^{2}$ per person. \\
\hline Sanitation & $\begin{array}{l}\text { Family latrines are preferred. Start with 50 persons per latrine and } \\
\text { lower to maximum of 20 persons per latrine (segregated by sex). }\end{array}$ \\
\hline Water Availability & $\begin{array}{l}\text { Basic water needs are 7.5-15 litres/person/day. Maximum distance to } \\
\text { nearest water point is 500 metres. }\end{array}$ \\
\hline Health Facilities & $\begin{array}{l}\text { Essential health services including control of communicable diseases, } \\
\text { child health, sexual and reproductive health, injury, mental health and } \\
\text { non-communicable diseases. One health centre/50,000 people with } \\
\text { qualified health workers (medical doctors, nurses, midwifes). }\end{array}$ \\
\hline Non-Food Items & $\begin{array}{l}\text { Minimum nutritional requirements of 2,100 kcal/person/day consists } \\
\text { of 10\% protein, 17\% fat and adequate micronutrient intake. }\end{array}$ \\
\hline Accessibility & $\begin{array}{l}\text { Rapid market analysis can determine whether goods can be sourced } \\
\text { locally or in neighbouring, non-affected areas. }\end{array}$ \\
\hline Transportation & $\begin{array}{l}\text { Access road should consider proximity to transport hubs for the } \\
\text { supply of relief assistance, seasonal constraints, hazards and security } \\
\text { risks. Escape routes should avoid isolated or screened areas that could } \\
\text { pose a threat to users' safety. }\end{array}$ \\
\hline Climate and & $\begin{array}{l}\text { Primary storage and food distribution accessible by heavy trucks from } \\
\text { an all-weather road. Other facilities accessible by light vehicles. }\end{array}$ \\
\hline Environmental Condition & $\begin{array}{l}\text { Shelter should provide protection from seasonal climate. Need to } \\
\text { minimize adverse impact on the local natural environment resources } \\
\text { when providing shelter to the affected population. }\end{array}$ \\
\hline Education and Activities & $\begin{array}{l}\text { Encourage community to organize structured and supportive } \\
\text { educational activities for children. Access to community-based social } \\
\text { support and self-help activities that promote psychosocial well-being. }\end{array}$ \\
\hline
\end{tabular}

\subsection{The United Nations High Commissioner for Refugee (UNHCR) - Handbook for Emergencies}

\subsubsection{Description}

The United Nations High Commissioner for Refugee (UNHCR) is mandated to lead and coordinate the international action for protection of refugees and the resolution of refugee problems [15]. The handbook defined refugees in any situation in which their life or wellbeing will be threatened unless immediate and appropriate action is taken. UNHCR's primary purpose is to safeguard the rights and well-being of refugees and others irrespective of their race, religion, political opinion or gender. General guidance on emergency assistance included in the handbook aimed to provide protection and ensure necessary needs of the refuges are met effectively and appropriately [15].

\subsubsection{Minimum standard for relief shelter}

Table 2 shows the minimum standards in emergency management according to the standards specified in the Handbook for Emergencies by UNHCR [15]. 
Table 2. Minimum standards in emergency management [15].

\begin{tabular}{|c|l|}
\hline Minimum Standard & \multicolumn{1}{c|}{ Description } \\
\hline Type of Shelter & $\begin{array}{l}\text { Plastic sheeting, light weight emergency tents (LWET), prefabricated } \\
\text { shelters. }\end{array}$ \\
\hline Living Area & Floor space of 3.5 $\mathrm{m}^{2}$ per person. \\
\hline Sanitation & $\begin{array}{l}\text { One latrine per family or communal latrines that not exceeding 20 } \\
\text { persons per latrine facility (segregation of sexes). }\end{array}$ \\
\hline Water Availability & $\begin{array}{l}\text { Minimum provision of 7 litres/person/day. Maximum distance to } \\
\text { water distribution point should not more than 100 metres. }\end{array}$ \\
\hline Food and Nutrition & $\begin{array}{l}\text { Priority should be placed on health programmes of measles } \\
\text { immunization, nutritional support, control of communicable diseases } \\
\text { and epidemics, reproductive health problem and public health } \\
\text { surveillance. One health centre per facility (20,000 persons). }\end{array}$ \\
\hline Non-Food Items & $\begin{array}{l}\text { General ration of 2,100 kcal/person/day (meet essential vitamin and } \\
\text { mineral requirements). }\end{array}$ \\
\hline Accessibility & $\begin{array}{l}\text { Assess goods that are readily available on the local market. } \\
\text { supplies, above flood level and have adequate drainage. }\end{array}$ \\
\hline Transportation & $\begin{array}{l}\text { Number of light and heavy vehicles should be determined. Ensure } \\
\text { sufficient trained drivers, fuel, lubricants, spare parts, tyres, } \\
\text { maintenance personnel and facilities. }\end{array}$ \\
\hline Climate and & $\begin{array}{l}\text { Free from major environmental health hazards and suitable year-round } \\
\text { climatic condition. }\end{array}$ \\
\hline Environmental Condition \\
\hline Education and Activities & $\begin{array}{l}\text { Provide learning activities in safe and child-friendly spaces. Non- } \\
\text { formal education included with full participation of the community. }\end{array}$ \\
\hline
\end{tabular}

\section{Methodology}

Field surveys were done by collecting data at the flood-affected areas and interviewing the victims to access the issues encountered during the 2014 flood event. The list of relief shelters that had been established were also identified which can act as temporary accommodation for the affected victims during a disaster. Collection of data involved combination or integration of qualitative and quantitative research methods. Qualitative data usually includes open-ended with emerging responses while quantitative data tends to be closed-ended with predetermined responses.

\subsection{Data Survey}

Field surveys were conducted at areas affected by 2014 flood event in Perak Tengah district, Perak. Survey activities were administered at 75 villages from 10 sub-districts in Perak Tengah which were Kota Setia, Bandar, Pasir Salak, Bota, Pulau Tiga, Lambor, Pasir Panjang Hulu, Layang-Layang, Kampung Gajah and Belanja. A number of 449 respondents were selected randomly from local people who were also the flood victims at the respective areas. Respondents were comprised of $69 \%$ female and $31 \%$ male ranged from teenagers to senior citizens. The age of respondents was majority ranged from 41 to 60 years old. Structured questionnaires were developed and used as a guidance while conducting the survey. The elements in the questionnaires consist of respondents' personal details, floodrelated information, experiences in facing the flood, condition in relief shelters, losses estimation, health conditions and psychological aspects. 


\subsection{Interview}

Interview sessions were carried out with the local authorities, related agencies and public community. The topics discussed during the interviews included flood management procedures, agencies involved in handling the flood, early warning and preparation, evacuation process, emergency relief shelters for the victims, distribution of supplies and assistance and mitigation measures for future flood disaster. Acquisition of data involved meeting and discussion with Perak Tengah District Council, District and Land Office of Perak Tengah, Department of Social Welfare of Perak Tengah, Department of Irrigation and Drainage (DID) Perak Tengah, Department of Civil Defence of Perak Tengah, Department of Public Works of Perak Tengah, Perak Tengah District Youth Council, district headman, villagers' head and flood victims.

\subsection{Observation}

Site observations were also done during the survey activities. Information related to flooding was recorded based from the observations at the surrounding areas. Facilities used as relief shelters during flooding were also visited as part of data collection activities. From the observations, relief shelters in Perak Tengah used existing permanent buildings to accommodate the flood victims. In most cases, the evacuees were located at the nearest shelters from their houses to facilitate the evacuation process during the flooding period.

\section{Results and discussions}

\subsection{Relief shelters in Perak Tengah district and its classification}

After disastrous impacts from 2014 major flood event, the authorities aimed to improve the disaster management system including early preparation and warning, risk reduction measures, immediate recovery and rehabilitation of affected communities. One of the initiatives in handling future flood disaster was provision of relief shelter locations that can accommodate the victims during the disaster period.

Table 3. Relief shelters distribution in Perak Tengah district.

\begin{tabular}{|c|c|c|}
\hline Sub-District & Number of Relief Shelter & Capacity \\
\hline Belanja & 15 & 2,770 \\
\hline Layang-Layang & 6 & 1,350 \\
\hline Lambor & 4 & 1,900 \\
\hline Bandar & 2 & 800 \\
\hline Bota & 16 & 6,000 \\
\hline Kampung Gajah & 5 & 3,250 \\
\hline Pasir Salak & 1 & 1,000 \\
\hline Pulau Tiga & 2 & 800 \\
\hline Kota Setia & 1 & 500 \\
\hline Total & $\mathbf{5 2}$ & $\mathbf{1 8 , 3 7 0}$ \\
\hline
\end{tabular}

Distributions of relief shelters in Perak Tengah district are listed in Table 3. The information was obtained from the Department of Social Welfare of Perak Tengah whereby the shelters can accommodate a maximum capacity of 18,370 persons at one time. A number of 52 relief shelters were established in Perak Tengah district to act as temporary 
accommodations for the community affected by a disaster. Shelters were chosen by related authorities as early preparation in evacuating and placing the affected communities in a well-managed situation during disaster period in the future. All of the shelters are permanent buildings whereby Fig. 1 illustrated the classification of the shelters according to their types including schools, public halls and mosque or surau. Majority of the shelters are schools $(63 \%)$, followed by public halls $(29 \%)$ and mosques or surau $(8 \%)$. The schools included were secondary and primary schools, religious schools, and training institutes. Most of the shelters were selected as the buildings were equipped with basic facilities including toilets, separate areas and suitable for a wide range of population.

From the collected data, relief shelters were categorized based on their maximum capacity. In Perak Tengah, the highest number of relief shelter is for the capacity of 200 and below where it contributes to $35 \%$ from the total number of relief shelters (Fig. 2). It is followed by 200 to 400 capacity ( $31 \%$ ), 500 to 700 capacity $(21 \%)$ and 800 to 1,000 capacity $(13 \%)$. It can be said that the existing shelters can accommodate certain number of people at one time due to the size of their buildings and surrounding areas. Low capacity shelters were public halls, mosque or surau and schools located at the rural areas. In addition, relatively there were also higher capacity temporary shelters that were assigned to Secondary School Sultan Muzaffar Shah, Mosque of Izzuddin Shah Bota, District Council's Public Hall, Institute of Agriculture Titi Gantong, Training Institute UITM Sg Galah, Primary School Dato' Sagor and MARA Junior Science College (MJSC) Pasir Salak.

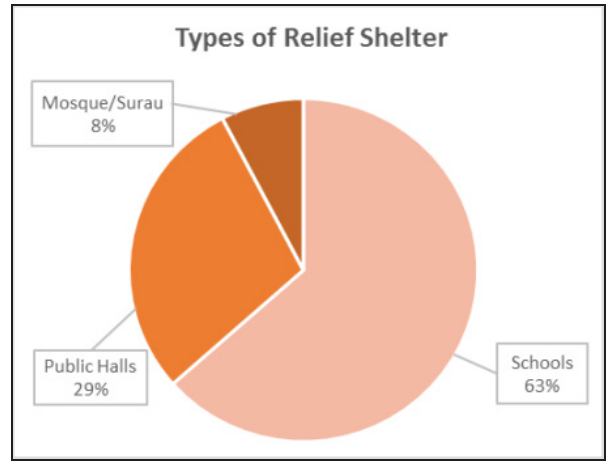

Fig. 1. Relief shelters based on their types.

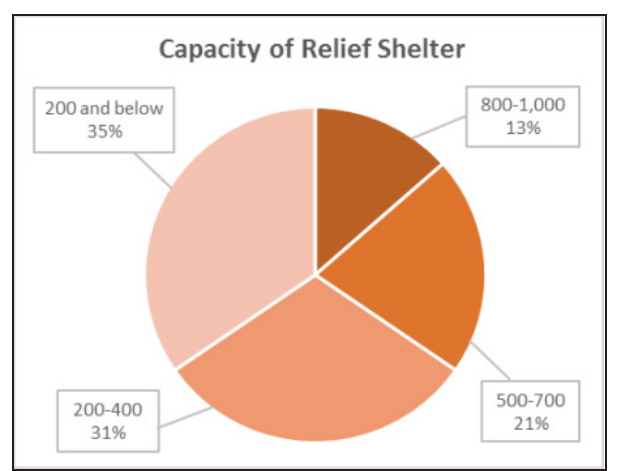

Fig. 2. Relief shelters based on their capacity.

\subsection{Issues during flooding and setbacks}

The survey conducted revealed several pertinent issues during the 2014 flood event. The issues highlighted in this study were related to situations or problems encountered by the victims during flooding and agencies involved in handling the disaster. Most areas in subdistricts of Kampung Gajah, Pasir Salak, Pulau Tiga, Kota Setia and Bandar were inundated for more than two weeks with some areas had been disconnected and normal access by land was temporarily hindered. As a result, Department of Civil Defence of Perak Tengah that acts as the rescue team stated that the distribution of food supplies, daily necessities and assistance to the shelters were disrupted.

In times of flooding, victims were evacuated to relief shelters as temporary accommodation until their actual houses are safe from any harmful conditions or risks of danger. During the peak of flooding, some of the relief shelters were also inundated resulted in relocation of victims to other shelters. This had caused difficulties to the affected victims in terms of relocation process, evacuation transport mode, sudden need to move and risk of danger due to rising of flood water level. Other than that, increasing 
number of flood victims also led to issues of crowded condition in the relief shelters. In case of emergency, victims were evacuated to the nearest centres. Instances where a high number of victims were placed in a relief shelter resulted in uncomfortable environment for the victims.

The prolonged flood inundation resulted in damages to building structures and disruptions to services and operation of the affected premises. Public buildings such as schools should be only used as short-term accommodation before providing more suitable shelters. Consequently, school sessions had been suspended due to inundation at the school areas, maintenance and repair works, recovery period and preparation for learning tools and materials. Besides, the infrastructure of the building including water, electricity and sanitation will deteriorate quickly from concentrated use to the extent that living conditions can become relatively unhealthy. Hence, the buildings may damage rapidly because they are unsuited to large number of occupants in a long period of time. In addition, low sense of responsibility by the users also contributes to the deterioration of the buildings.

In Malaysia, there is no implementation of standards or guidelines for relief shelters as temporary accommodation for the victims during a disaster. Properly designed and strategically located shelters based on acceptable standards are crucial to ensure practical, conducive and safe shelters for the victims. Therefore, relief shelters in Malaysia should be improved progressively in terms of strategic locations, optimum covered area for victims, availability of health facilities and sanitation, sufficient source of food and water, transportation, secure accessibility and more importantly conducting community-based activities to promote a balanced psychosocial well-being for the victims.

\section{Conclusions}

From the highlighted issues encountered during the 2014 flooding, appropriate planning and management strategies should be implemented to substantially reduce the inconveniences and risks to the victims during disaster. Besides, the use of public buildings as relief shelters may not only affect the formal usage of such premises but it may also not able to offer the convenience and appropriate facilities, especially for much longer stay. Capacity of the relief shelters reflects the maximum occupants that should be placed in the buildings at one time to provide safe and conducive environment for the affected victims. Furthermore, it is important to ensure regular operational maintenance of the buildings in order to maintain good facilities throughout the usage period. Establishment of dedicated relief shelters should be considered for future preparedness so that healthy environment can be maintained as well as to reduce the damage effects from the disaster.

The initial part of the research was partially funded by FRGS grant (FRGS/1/2015/TK02/UTP/02/6). The authors would also to thank the Centre for Graduate Studies and Department of Civil and Environmental Engineering, Universiti Teknologi PETRONAS for their support and encouragement.

\section{References}

1. B. Pradhan, Spatial Hydrology 9, 1-18 (2009)

2. M. Haq, M. Akhtar, S. Muhammad, S. Paras, J. Rahmatullah, The Egyptian Journal of Remote Sensing and Space Sciences 135-141 (2012)

3. M. Saharia, P.E. Kirstetter, H. Vergara, J.J. Gourley, Y. Hong, J. Hydrol 548, 524535 (2017)

4. Malaysian Medical Relief Society (MERCY), Malaysian Flood Emergency Response Donor Report (2014) 
5. M.S. Khalid, S. Shafiai, International Journal of Social Science and Humanity 5, 398402 (2015)

6. M.M.A. Khan, N.A. Shaari, A.M.A. Bahar, M.A. Baten, D.A.B. Nazaruddin, World Applied Sciences Journal 32, 4, 626-634 (2014)

7. A.Z. Othman, A. Dahlan, S.N. Borhani, H. Rusdi, Procedia - Social and Behavioral Sciences 234, 125 - 134 (2016)

8. M.N. Halgamuge, A. Nirmalathas, Int. J. Disast. Risk Re. 24, 1-11 (2017)

9. C.S. Mustaffaa, N.A. Marzukia, M.T. Ariffina, N.A. Salleha, N.H. Rahamana, Procedia - Social and Behavioral Sciences 155, 197 - 202 (2014)

10. A. Bashawria, S. Garritya, K. Moodleya, Economics and Finance 18, 924-931 (2014)

11. Humanitarian Charter and Minimum Standards in Disaster Response (The Sphere Project, United Kingdom, 2011)

12. B. Kar, M.E. Hodgson, Transactions in GIS 12, 227-248 (2008)

13. M.R. Rateau, Archives of Psychiatric Nursing 31, 561-565 (2017)

14. The International Federation of Red Cross and Red Crescent Societies (IFRC), Shelter and Settlements Standards. Retrieved January 5, 2016 from http://www.ifrc.org/en/what-we-do/disaster-management/responding/services-for-thedisaster-affected/shelter-and-settlement/shelter-library/standards/

15. Handbook for Emergencies, (United Nations High Commissioner for Refugees, UNHCR, Geneva, 2007) 